\title{
The COVID-19 pandemic and the state: is it emerging a new configuration of public administration?
}

JOSEP PONT VIDAL ${ }^{1}$

${ }^{1}$ Universidade Federal do Pará (UFPA) / Núcleo de Altos Estudos Amazônicos (NAEA), Belém - PA, Brazil

\begin{abstract}
The impacts of the COVID-19 pandemic led the state to accelerated ongoing reforms regarding its scope, responsibilities, and operation model. These have also affected public administration and its autonomy and configuration. This period of contingency may mean a horizon of possibilities, or to an open horizon of change. The state can be oriented towards horizontal and participatory structures and methods or vertical and centralized hierarchies. In this extraordinary situation of complexity, contingency, and uncertainty, it seems necessary to ask about the theoretical concepts and methodologies available in the areas of study of political science and administration. These questions led us to point out potential directions taking shape in the Brazilian state and public administration.
\end{abstract}

Keywords: Public administration. Pandemic COVID-19. State reform. Contingency. Risk.

Pandemia do COVID-19 e mudanças no Estado: surgirá uma nova administração pública em resposta essas mudanças?

\section{Resumo}

Como consequência dos impactos causados pela pandemia de COVID-19, o Estado acelerou as reformas já iniciadas em relação a sua extensão, responsabilidades e modelo. Isso também impactou a administração pública e sua autonomia e configuração. O cenário vem de uma situação de contingência, que pode significar um horizonte de possibilidades não impossíveis, que é equivalente a um horizonte aberto de mudança. O Estado, ele pode ser orientado para estruturas e métodos horizontais e participativos, ou para hierarquias verticais e centralizadas. Nesta extraordinária situação de complexidade, contingência e incerteza, parece necessário questionar os conceitos e metodologias teóricas disponíveis nas áreas de estudo da Ciência Política e Administração. A partir dessas questões, ilustramos com a direção que está se formando no Estado e na administração no Brasil.

Palavras-chave: Administração pública. Pandemia COVID-19. Reformulação do Estado. Contingência. Risco.

\section{Pandemia de COVID-19 y Estado: ¿Hacia una nueva la configuración administración-Estado?}

\section{Resumen}

Como consecuencia de los impactos causados por la pandemia de COVID-19, el Estado ha acelerado reformas ya iniciadas referentes a su alcance, responsabilidades y modelo. Estas también han tenido impacto en la administración pública y en su autonomía y configuración. En escenario deviene de una situación de contingencia, que puede significar un horizonte de posibilidades no imposibles, lo que equivale a un horizonte abierto a cambios. El Estado puede orientarse hacia estructuras y métodos horizontales y participativos, o hacia jerarquías verticales y centralizadas. En esta situación extraordinaria de complejidad, contingencia e incertidumbre, parece necesario cuestionar los conceptos y metodologías teóricas disponibles en las áreas de estudio de la Ciencia Política y la Administración. A partir de estas cuestiones, los ilustramos con la dirección que se está perfilando en el Estado y la administración en Brasil.

Palabras clave: Administración pública. Pandemia COVID-19. Reformulación del Estado. Contingencia. Riesgo. 


\section{INTRODUCTION AND CONTEXTUALIZATION}

The global Coronavirus disease (COVID-19) pandemic has became broader the models and transformations of the State and administrations that were already underway. Insofar a State is being claimed present in all areas, administrations will have to face very unstable conditions, such as changing the economy and reformulating methods quickly, paying massive attention in very limited times in a context of high complexity or hypercomplexity. Add to these circunstances, the measures and decisions that governments around the world had to take regarding restrictions on constitutional freedom, such as population confinement, movement restriction, massive surveillance and control using the possibilities of big data analytics, coercive measures, etc. Thus, three different areas converge: (a) the State model; (b) the impacts on administrations; and (c) the specific governance accomplished. These changes and transformations in economic, political, administrative and control aspects are not appearing just in this exceptional situation, but have already been taking shape for some years.

Thus, there are also possibilities to introduce or accelerate structural changes, according to the model of the State and its governance, once the generalization of the information and communication technology possibilities have already started a few years before with ardent supporters (CHUNG-PIN, CHANG and BERRY, 2011); however, the implementation of new possibilities for surveillance and control can also be definitively established, being seen with suspicion. In Brazil, many publications have dealt with this issue (ABREU, 2016), considering the possibilities of big data analytics and its still incipient implementation and distrust, warning about its dangers (COSTRA and DUTRA, 2014; OLIVEIRA, 2018).

Is a new type of State definitely being set up? In what direction is the relationship between the State and the administration oriented? How do they manifest themselves in the administration field? Will disempowerment be established or declining decision-making capacity of parliaments? In this scenario of generalized uncertainties, the emergence of the COVID-19 pandemic has brought internal and external changes to the State and administration (changes in the link with the State) already initiated and evident in recent years. The main changes are summarized in two. In both, their limits and paradoxes also emerge. First change - two models of the State are outlined, ranging from the extensive State to the reduced State, claimed by different political and social forces. Second change - in this transformation context, it may mean that the administration will be affected in its autonomy and its action capacity, depending on the State model that is imposed. This situation has already been conceptually diagnosed with the crisis of the so-called Welfare State or "Dual State" ${ }^{1}$, in the case of Brazil.

With the questions exposed, a dialogue is proposed with the political and administration sciences, and inevitably the folowing question arises, "Which theoretical concepts with interdisciplinary capacity do we have for analyzing these ongoing transformations?". In this scenario of uncertainties, the contingency is about a reaction to an eventuality or an unexpected event, in this case, the COVID-19 disease pandemic and the open possibilities that it involves. We do not use the contingency concept here as the selection of multiple possibilities in relation to complex situations or eventualities, but rather it is oriented to philosophy and logic and to contingency, in particular; under the self-referential system perspective, it is the way of being of what is neither necessary nor impossible, but what may be or may not be. It is the characteristic attributed to the entity, whose existence is considered not needed but not impossible, at the same time. Its reality cannot be definitively demonstrated or denied (VIDAL, 2020). In the State analysis field and its relationship with the management of this paper, there is no certainty of what the State should be in one way or another, nor what kind of management might be in the coming years, in the post-pandemic scenario, because different and not impossible opportunities open up and can happen. In this situation, the risk of future extremist or autocratic governments will be present. This contingent situation is possible to be repeated in all societies.

These hypothesis are supported by two substantive variables. The first variable deals with the possibility to definitively incorporate changes in the State orientation and in its expansion of service co-production, although its orientation is subordinated to the kind of governmental action. The second variable refers to the impacts on the administration, in particular, on its autonomy, extension, and decision-making capacity. It is evident that these questions cannot be exposed and analyzed in depth, or confirmed empirically, but only raised in a conceptual introductory perspective, which is illustrated only with many journalistic publications.

\footnotetext{
${ }^{1}$ For more details, see Barba Solano (2007).
} 
This paper is structured in three sections. In the first section, we address the methodology on which the interdisciplinary dialogue and the complexity conceptual presentation necessarily come from, and we establish a dialogue with the concepts used to present the topic, contingency, and risk. In the second section, we expose the conceptual delineations, outlining and configuring the State and the administration in Western democracies. In the third section, on the basis of this description, we focuse on and illustrate the governance and profiles drawn from the State models and, in particular, the performance of the Brazilian government in communicative and administrative actions.

This paper does not intend to answer the questions asked exhaustively or conclusively, due to the lack of available empirical analogical deductions and the uncertainties created today, but rather to raise questions about the hyper-complex scenario presented to us.

\section{WHICH THEORETICAL CONCEPTS DO WE HAVE TO DESCRIBE THE CURRENT SCENARIO?}

We proceed under the hypothesis that we find ourselves in a highly complex situation that requires an interdisciplinary dialogue.

However, in political science and in sociology, mainly concepts and theoretical currents that showed their limits are still been used, either in their explanatory structures, or in the application of concepts (VIDAL, 2018, 2019). Neo-institutionalist currents and Marxist theory have been hegemonic in political science, simultaneously with other theories (game theory, Foucauldian approach), whereas the theory of basal systems (open) in administration has also dominated. The rational choice theory like neo-institutionalism lead to the paradox of the expectation of the human being's rationality. The administration has also been based on open systems theory and on binary input-output logic, without autonomous decision-making capacity, an aspect restricting the system's ability to communicate with its environment.

Thus, it seems neeeded to seek and to develop concepts with enough explanatory capacity for observing the current post-pandemic scenario and the tragic impacts that it involves. In this argumentative context, the optics of self-referential systems theory provides a descriptive and comprehensive framework for the current high complexity.

Presenting societies as complex involves prioritizing the understanding that the number of possible relationships among elements of the social system (or of a particular subsystem) increases exponentially as increasing the number of the own elements. Thus, when there are four elements (or possible variables), they form sixteen possibilities of types of relationships and so on. As a consequence, making selections is needed when increasing elements, since they are not controllable by the system. The consequence is that the system cannot be updated simultaneously. Taking on the idea of complexity represents, on the one hand, moving away the presentation of class struggle as an engine of social change and, on the other hand, the idea of order. The emergence of the COVID-19 pandemic is a clear example of this situation.

In this line of argument, we propose to describe the concepts of system, polycentricity, and communications in a framework of contingent changes. On the other hand, we approach the emerging guidelines in Western countries according to the model and governance of the State and administration, although, here, it is needed to establish a difference between the State model and government action.

By State model, we understand its sphere of functions, size, and the corresponding political-administrative and economic orientation, which, in this context, we call as reduced State in its polycentric or multicenter presentation, and as extensive State in its corresponding theoretical description of State-centered. By government action, we mean the set of actions and decisions taken by a specific government during the time exposed here. In both cases, paradoxes appear regarding the type of State intervention and the economy regulation.

The illustration of these concepts and how these factors have manifested in the political-administrative sphere during the pandemic in Brazil has been acquired basically from two sources, namely, the first source from the official sites of the Government and its communication bodies ${ }^{2}$; the second source, through the main mass media (written and televised) from March to August, 2020.

${ }^{2}$ Consulting communications from government agencies, basically, "Diário Oficial da União, Ministério da Saúde, Casa Civil da Presidência, and TV Brasil". 


\section{Hypercomplexity, contingency, and risk}

Complexity - high complexity or hypercomplexity - characterizes today's modern societies, formed by an extensive and dense political-administrative and legal organization at multiple levels. These societies are increasingly geared to the type of joint, conventions, and mediations towards highly complex systems and interactions. In this type of societies, the joint among government and institutions in their different levels, the functioning of autarchies, the managing demands and emerging conflicts, the metropolitan areas, and the international relations are increasingly characterized by wide hypercomplex processes on many occasions with diametrically opposed interests. This fact gives rise to the latent emergence of social conflict. Society as hypercomplex context presents challenges, since complexity involves contingency, contingency inevitably involves risk, and risk in turn involves danger.

The COVID-19 pandemic has showed high complexity or hypercomplexity in all its dimensions and in the innumerable intervening variables, such as: (a) incompatibilities among the economy, health, and science; (b) paradoxes and contradictions in decisions at different levels of government in all countries (whether federal or decentralized); (c) many logics and strategies to combat this pandemic; (d) fighting the pandemic versus government decisions; and (e) multi-level articulation among governments, states, and the World Health Organization, etc.

Under the perspective of this paper, the term complexity is used as a multidimensional concept, to which two meanings are basically understood. In the first meaning, complexity is the point of view that most strongly expresses the research issues in modern systems theory, as it cannot be defined without the existence of systems or areas. Under this perspective, the notion of complexity has taken on a role that catalyzes the set of intervening variables, without being able to define it. The complexity is given by the selectivity operations from the system's own limits. These limits should also be considered as special devices for the coupling and separating function upon specific selection fulfillment. The selectivity inherent in the location and demarcation of limits in each system not only helps to reduce the system internal complexity, but also its external complexity.

The internal organization of each system is based on a "selective relationality", that is, a selection based on principles of the rationality proper to the system. This operation causes partial systems (economic, legal, political, administrative, among others) to be indeterminate among themselves, needing the communication for their regulation.

In the second meaning, "organized complexity" only takes place in the systems formation, when meaning complexity also in the selective relationships among the systems. Under the self-referential perspective, when increasing the number of elements within a system, or that one system is part of the environment of another, it becomes extremely impossible to relate all the elements. Here, the complexity concept appears in its presentation of "organized complexity" that only is formalized through the system formation. Thus, complexity is like a self-conditioned state of affairs, since its elements must be completely constituted to converge as unit at the higher level of he system formation, since their coupling capacity is limited in systems. In sum, complexity means coercion to select, coercion in selection means contingency, and contingency means risk. Thus, in the complexity, contingency inevitably appears with the adjective of multiplicity, since there cannot be a single contingency but a multiplicity of contingencies, depending on each observer.

\section{Contingency and risk}

Like contingency, risk and danger form a dynamic and continuous sequence and have become clear in the management of the coronavirus emerged in China in December 2019. At first, the World Health Organization (WHO) admitted a mistake in disclosing the global risk of the new coronavirus on January 27, 2020. Initially, this organization have classified the risk as "moderate", being later corrected as "high", and afterwards have reported that the risk is "very high in China, high regionally, and high globally". The imperceptibility of the dangers, their supranationality, the "ecological expropriation", and the transition from normality to absurdity were already diagnosed by Beck ([1986] 1998) on the occasion of the Chernobyl nuclear accident in 1986.

Under the perspective that we present here, contingency is what is neither needed nor impossible and can always exist, involving necessarily risk, and risk, in turn, involves danger. For Luhmann, in addition to the ontological predicates "to be" 
and "not to be", contingency also involves a third value, namely, "indeterminability". The contemporary "era of uncertainty" (LUHMANN, 1998, p. 45-46) is nothing more than a particular version of modern society, whose defining attribute is contingency. In modern conditions, needs and impossibilities no longer provide the ordered structure of the world. There are no longer socially needed forms for the reciprocal limitation of the different components of society or even for the social coherence of the whole. It is accepted that everything that is supposed can be different, and that anything, although not all at once, can be redefined and changed through communication. Modern society is a contingency-embracing society like no other before. Although needs and impossibilities are accepted for reasons of time, this type of society, in line with its acceptance of contingencies, is characterized especially by weak attributes required in the sense of initially undeterminable emerging properties, highly improbable and fragile.

It should be obvious that, under contemporary conditions, both science and politics, as well as their relationship to each other, can no longer be conceived according to needs, but must be analyzed according to these emerging fragile and improbable properties of society. At the same time, however, it must be remembered that nothing is also considered impossible under these conditions.

How can risk be defined? The different thoughts of philosophy and the social sciences have assigned different meanings to it. In the rationalist tradition, it has been considered as the product of a decision that could have been anticipated or avoided, according to its subsequent (negative) impacts. Here, it deals with a temporal calculation with the horizon of an uncertain future, whose impacts could be avoided. Risk situations that contemplate it may be admitted, as long as the possibility of occurrence is justified (construction of large dams, polluting companies, experimentation with new viruses, production and storage of chemical products, etc.). This has been the prevailing argument. Niklas Luhmann has inquired the traditional concept of contingency because it is limited, since the risk can only be described in its quantitative and probabilistic aspects and can be analyzed basically in the economic and scientific system. The observation of the first degree does not allow the deep analysis of the human being reasoning logic, which does not calculate the rational predicate properly, and constantly makes mistakes (LUHMANN, 2006, p. 46).

The WHO had already published a report in 2019 (GPMB, 2019), anticipating the possibility of a global pandemic caused by an unknown virus, and the need for governments to prepare for such situation. The risk of a pandemic hatching was not assumed by any Western country. Also, the WHO minimized the possibility of a pandemic in this range in January 2020.

The risk approach and observation in differentiation involve elementary observation and second-degree observation. Observation of the first degree is the real world, limiting, therefore, to be able to identify possible risks only quantitatively. With the use of the binary risk-security concept, the observations are only to guarantee security, for which, more and better types of information are needed. For this reason, it is proposed that the theory must be led to second-order observation. It is a "multiple contingency" phenomenon, that is, it allows and offers to approach it under different perspectives by different observers. The problem here is that the risk is something that is described as similar by different observers. The consequence is that very different information is generated among them. At this point, the proposal is the differentiation between risk and danger. Whereas the risk refers to the fact that the challenge is the consequence of the decision, already for the danger, the possible damages are caused externally, that is, attributed to the system context. Second degree observation allows to distinguish between those who decide what the risks are and those who are affected by them.

The economy is the area in which risk has usually been considered (moderated by insurance). Here, the risks are those dealing with temporary differences in the use of money (linked to investment and credit), in which a failure in production is considered a danger, not a risk. Thus, for the economy, the central risk is the possibility of not restoring the payment capacity. The second-order observation is aimed at observing the calculation in the economic system, considering that competition and the desire to stay in the market lead the economic agents to observe not the economy but how competitors behave to reproduce their own behavior. In an individual sense, risk would be a kind of coercion that encourages recklessness, whereas, in the social sense, it is an increase in willingness to risk (debt ratio, global debt). 


\section{RECONFIGURATION OF THE STATE-SOCIETY TIES}

Most of the forecasts and researches carried out in recent years on the administration, role, scope and responsibilities of the State have been mostly obsolete, others will be reinforced by the speed and impact of events, and others today have won the contours of systemic governance (VIDAL, 2018, 2019). The reconfiguration of the State-society ties incluyes different levels and fields of analysis, such as politics and forms of government, society, management, public administration, social security, etc. The postulates of the New Public Management (NPM) match to a delineation of the administration-State relationship, being the boost for renewing administration during the last quarter of the last century. However, the NPM has not been free of controversies, highlighting among them the neo-Marxist currents and the conservative perspective of management. Among the former, the criticisms under the perspective of the State model stand out, addressing its very close connection with the economy, when promoting the disassembly and reduction of the State, being "hostile to the State", and disassembling the foundations of participatory democracy. For the conservatives, the NPM has interfered too much in the administration regulation. From the insoluble problem between State-economy or administration-economy, the contradiction results, according to which the economy will always seek to maximize benefits, whereas the State must be leaded towards the common good.

\section{Models of public administration and multilevel governance}

This situation of things has been reflected on administration studies. These studies have found themselves at a crossroads, basically for two reasons: (a) due to the obstacle to describe the changing and dynamic nature of the administration; and (b) due to critical publications on the poor institutional performance of the administration. This situation was a reflection of a context that has already pointed to the crisis in the State spheres, by separating activities, which perhaps should never have been taken on.

At the same time, the New Public Management (NPM) movement that has started in the late 1990s was implemented in many countries, although with different results among those of Western Europe and Latin America. In Brazil, this movement acquired its own profiles, in relation to time and application, as many studies have found (CAVALVANTE and CAMÕES, 2015). The hypotheses have been widely analyzed and discussed among their defenders and among their critics, when announcing "the failure of the new management model" based on its contradictions (BOGUMIL, 2007).

On the other hand, traditional decision-making structures, in which administrations and politicians maximize utility and tend to expand their hypotheses, have also been questioned under the perspective of rational choice, taking into account two reasons. The first reason is referring to the rationality of traditional decision-making structures. The departmental and political services that seek advantages to try increasing their economic budget were not as rational as initially thought, but multiple paradoxes emerged. The second reason, when presenting the new management model as more suitable for the management of human behavior, it was understood that the traditional control model has failed, both in the level of application of theoretical concepts and in practice, due to the contradictions that arose in behavior management.

In this situation, under the perspective of self-referential systems in describing the changes in the administration, the contribution is innovative, as it is reasoned on certain premises. The administration is defined as an autonomous system with a differentiation related to the bureaucracy, formed by hierarchies in asymmetric structures, which are manifested in hierarchies and in the use of power. The socio-political function of the administration demands a rationality that means a degree of dynamic differentiation and capacity for self-determining its behavior and operations. As a system with a specific organization, it has the function to produce binding decisions on problems under the the hypotheses of a complexity previously reduced by the decisions made in the political system. In the administration, political processes have already taken place beforehand in the political system, whose results are transformed into inputs and information for the administration. Thus, in Brazil, decisions on emergency aid and administrative and health governance of the pandemic were earlier political decisions to reduce the situation complexity, regarding the construction of hospitals, availability of Intermediate Care Units (ICUs), hiring of Cuban doctors or students of the last semester of medicine, and measures to acquiring health material. The same procedures were happening with the applied models for population confinement and unconfinement

Internal management decisions are made with the help of politics, hence the system can achieve a high degree of complexity and decision-making capacity. Luhmann ([2010] 2014), outlining two types of complexity, commented on undetermined complexity 
and determined complexity. Whereas in the first case politics has a specific role in the administration, in the second case, this premise is not satisfied, since the administration depends on a link network with society. With the examples presented, it is a kind of indeterminate complexity; in the case of contingencies and paradoxes arising from multilevel governance (in Brazil there have been frequent disagreements among the President of the Republic, the Government, State Governors and Mayors), it is a determined complexity. On the other hand, the autonomy of the administration, in turn, can be differentiated in three dimensions: (a) the social, referring to the objects with which it acts; (b) the objective, in the sense of its decisions; and (c) the temporal, in the decision processes.

\section{Pandemic management: self-excluding models and their paradoxes}

In this context, a contingent post-pandemic scenario emerges, opening up uncertainties and also new possibilities, since the appearance of new viruses or new strains of COVID-19 is not impossible. State and administration changes must be explored under the perspective of hypercomplexity, characterizing modern societies. In the systemic sense, complexity means contingency, and contingency involves risk and danger. So, something is neither impossible nor needed but it can be. This double negation leads to ambiguities, and, therefore, to different interpretations. For the idea presented in this paper, it is highlighted that any proposal for change in the governance and in the orientation model of the State is possible and, therefore, can be effective, although other possibilities will always remain open. The important question for us is, "In what direction is this change in orientation taking place?". Here, there is a great challenge for liberal democracies, State, and administration.

We will not dare to present hypothetical models for the future, but tather models already emerging: (a) reduced State and economic continuity; and (b) extensive State (or State-centric). Both already exist in many countries and are going to expand in the near future. Under the perspective of complexity, paradoxes appear in both models.The administrative system autonomy concerning to politics can take on two different phenomena; on the one hand, not being subject to the interested control of the political system and, therefore, favoring its elementary administrative function; on the other hand, it can acquire a prevalence in relation to the political system so that it is left without any kind of political control.

With the governance of the COVID-19 pandemic, the limits and capacities of the governance models, the functions and attributions of the State, its paradoxes, and consequently the outlining and deepening of the trends already started and in progress, referring to the State model that is being configured, have become evident. It has been repeated that the intention of the governments to confine the population (horizontal or vertical, "herd immunity", intelligent confinement) obeys the logic to avoid the health system collapse in each country. Each of the national health systems has a maximum care capacity for those infected, and a limited amount to serve them. To avoid collapse, in the event that there is no possibility to attend to all needed cases on a determined date, it has been important that the number of infected people do not exceed, at any time, the maximum that the health system can manage and attend. Therefore, it is imperative that the curve of patients in need of medical attention remains as flat as possible for the longest period of time, instead of a curve of rapid ascension for a short time, until reaching the peak of cases attended. On the other hand, it has also given the scientific system more time for the development of a treatment, or the development of a vaccine.

Vertical confinement has followed the logic to avoid economic downtime in the affected countries as much as possible with the argument that the impacts of the pandemic on the economy will be worse, destroying the country's wealth and jobs base. People over 60 years old or with chronic diseases were the population intended for confinement, measure recommended and followed by Great Britain, North America, Brazil, and even Sweden in the pandemic initial pase. On the other hand, horizontal confinement involves most of the population. It may be an irregular confinement, when, to be effective, it is recommended that $70 \%$ of the population should be confined and must be accompanied by a preventive test, targeting the sources and the people where the pandemic has begun. This procedure was used massively in Germany and showed to be the most effective, being the European country with the fewest deaths. To what political-administrative and understanding logic of the state does each model correspond? We have made a sketch that corresponds to two logics, "Reduced state" and "Extensive state (State-centric"). Both models are free of paradox. 


\section{Reduced State}

The proposal to reduce the size and reshape the functions of the State is not new and has been manifesting recently in a political context of liberal democracy crisis with the emergence of radical populist parties and movements, and the replacement by autocratic regimes. It can take two different forms, a centralizing state organization and a polycentric organization. In the context of the economic crisis (impacts of the Great Recession of 2008), it is intended to reduce decision-making levels at the multilevel plan, eliminating structures that can hinder rapid decision-making. Since some years, this procedure has been implemented in North America with the prioritization of individual responsibility in all areas (education, health, employment, retirement), which means that the state will not be responsible in risk and social danger situations. The economic system must be left to private initiative with minimal State intervention.

The COVID-19 pandemic management has shown the contingency of this model. Vertical confinement could have been established, if there had been a health system with the capacity to attend the whole population with quality for an exceptional situation such as this pandemic. Taking on a vertical confinement means that the country should have an exponentially more extensive and broader health system for the population (in principle, without exclusion for emergency situations such as the current one) at the quantitative and qualitative levels. But with this pandemic, its paradoxes have also appeared, claiming citizen movements (often from the extreme right) of civil freedom against control methods, surveillance, confinement, and punishment considered coercive.

\section{Extensive state: "State-centric"}

The pandemic has also favored the possibility for many publications to predict the expected collapse of the free market or the capitalist system. The considerations are ranging from apocalyptic visions of the future (exclusively imaginative) to more realistic predictions. For progressive political sectors (so-called left), the confinement has had a virtue and prediction, that is, with the temporary extension of the COVID-19 crisis, the economic order will also change enormously, just like we have known. The outlook is that the market economy, as it is known, is likely to be partially abolished, in which the private property and the competition will be less important, and the influence of the state will increase massively. On an analytical level, the State-centric theory is thus retaken, being the State the main producer of social welfare, meaning also paradoxically greater bureaucratic control and administrative centralization and control over the population, as it has already begun during the pandemic.

Paradoxes also appear in both models, since a reduced state can favor forms of government such as self-government, self-organization, self-regulation, or glocalization ${ }^{3}$, whereas an extensive state would tend to absorb initiatives of this type, in favor of centralized and homogenizing state policies in a globalizing economic context. This dilemma would appear in federal or decentralized states. How do these two types of State and governance options manifest themselves in post-pandemic situation in Brazil?

\section{BRAZIL: PRE-VIRUS CONTEXT}

The situation in the country in 2019, before the COVID-19 pandemic, was already worrying with austerity measures implemented by Michel Temer's government, when $50 \%$ of the population (that is, 104 million citizens) have a per capita income of $\mathrm{R} \$ \mathbf{4} 3.00$ [four hundred and thirteen reais (Brazilian currency)] per month; $5 \%$ of Brazilians (that is, 10.4 million) survive with $\mathrm{R} \$ 154.00$ [one hundred and fifty-four reais (Brazilian currency)] per month (PNAD 2019, IBGE). This historical situation of emergency and structural poverty also appears in the high unemployment rates with 12.6 million individuals, and $41.4 \%$ of workers are in informal work (IBGE/PNAD, 2019). Because of the homelessness, about 12 million people live in shantytown (IBGE). In addition, there is a high recurrence rate of sick people, largely due to socio-economic factors and the lack of basic sanitation in most cities of the country. ${ }^{4}$ This situation is framed in a context of inadequate health logistics, qualitative and quantitative, to face the imminent pandemic, to which the freeze on primary expenditure approved by the government of President Michel Temer (2016-2018) for a period of 20 years has contributed.

\footnotetext{
${ }^{3}$ Glocalization is a combination of the words "globalization" and "localization" and was initially developed in the 1980 s within Japanese commercial practices. The term is used to describe a product or service that is developed and distributed globally but is also adjusted to accommodate the user or consumer in a local market.

${ }^{4}$ According to the Audit "Cidadã da Dívida", the total Gross Domestic Product (GDP) is distributed as: "4.21\% for Health, 25.25\% for Social Security, 3.42\% for Social Assistance, and 3.48\% for Education".
} 


\section{Arrival of COVID-19: government decisions and communications}

The COVID-19 pandemic in Brazil has spread fastly as in all countries. The decisions and communications of the political system from February 26 (with the confirmation of the first case of COVID-19) to August 9, 2020, have been decisive in pandemic management with more than 100,000 deaths and more than 3,000,000 infected people. The pandemic has happening at the same time that an unprecedented health, economic, and institutional crisis, although it has not been the only Western democracy in this situation. ${ }^{5}$ For the purpose of this paper, we will focus on the analysis of government communications and codes.

On March 17, 2020, the first death from the COVID-19 was registered in São Paulo City. From this date, and in view of the fast and uncontrolled increase in infection contagions, cities and metropolitan areas have begun to establish different forms of quarantine (with the closure of schools, universities, religious cult centers, cinemas, shopping malls, restriction of crowds, etc.). Later, the decisions of the governors are added. The President of the Republic, Jair Bolsonaro, has expressed that the actions of governors on isolation affect the economy, and proposes "vertical confinement" as an alternative for people over 60 years old and at risk situation. On March 24, 2020, he made a statement calling for the "return to normality". Due to the dramatic situation of the increase in cases and infected medical staff, the Ministry of Health announces the hiring of 5,000 Cuban doctors and newly trained medical students. ${ }^{6}$ The Minister of Health, Henrique Mandetta, defends broad social confinement. However, the confinement rate has not reached the needed $50 \%$ in many cities. On April 22, 2020, the President of the Republic dismissed the Minister of Health, being replaced by Nelson Teich. At the first moment, the Minister has announced to create a program, concentrating information on the pandemic with new containment measures and the gradual return of economic activities, as well as the loosening of previously implemented social isolation measures. Four weeks later, he resigned and was replaced by Military Commander Eduardo Pazuello (as interim minister). In the absence of a unitary government communication, only two states establish the lockdown or complete closure (Pará and Maranhão) and some isolated municipalities, whereas other states and municipalities take on some random forms of confinement, according to the criteria of each governor and not coordinated with each other.

Scattered but not contradictory communications are also issued by the Ministry of Justice and Public Security (with the replacement of Sergio Moro by André Mendonça), and in the Ministry of Education (with the replacement of Abraham Weintraub by Carlos Alberto Deostelli, who came to be named, but did not take office, and finally by his sucesor, Presbyterian Pastor Milton Ribeiro).

Due to the national urgency of the situation and the impacts among the most disadvantaged classes and sectors, the government is forced to implement a set of emergency measures - "emergency aid" - for low-income families (informal workers, mothers head of the family, family enrolled in the "Bolsa Família" Social Program, representing approximately 97 million citizens). Its implementation (as of April 3, 2020) is delayed due to bureaucratic and technical problems, and derived from the fact that some 10 million citizens lack familiarization with the internet applications (apps). The main actions taken by the government consisted of financial assistance, in local currency (Real), which are:

- emergency aid for three months in the amount of $R \$ 600,00$ (six hundred reais) for 51.4 million people registered in the Single Registry of the Federal Government, representing $70 \%$ of the people registered in the databases. The half value is extended for another two months ( $R \$ 300,00$-three hundred reais);

- emergency aid to more than three million women heads of families (single parents). Aimed at:

- mothers in single-parent families, who raise their children under the 18 years old alone (first term of $\mathrm{R} \$ 1,200$ one thousando two hundred reais) two times,

- women without a husband or partner and with children or adolescents up to 18 years old (value of $R \$ 1,800$-one thousand and eight hundred reais), approximately 2 hundred thousand families,

- 1.5 million mothers; and

- families registered in the Unique Registry and beneficiaries of the "Benefício de Prestação Continuada" (BPC, Brazilian acronym) (Continuous Installment Benefit), exempt from the electricity bill, and registered in the Social Rate of Electric Energy (with electricity consumption equal to or less than $220 \mathrm{kWh}$ per month).

${ }^{5}$ Situations with these coincident factors also occur in Spain.

${ }^{6}$ It should be noted that these doctors were already sent back to Cuba in 2019. Their situation in Brazil was always been questioned, including the fact that they received only $20 \%$ of the salary fully paid by the Brazilian government. 


\section{Communicative intersystem rationality}

During the pandemic, the opposite asymmetries of communications and their respective codes have been evidenced among the economic, scientific, and health spheres, or systems. This case has led to an open conflict of counterpointed interests in aspects of the type and strategy of confinement (horizontal, vertical, intelligent, etc.), deconfinement (gradual, total), and in health management (purchasing model, logistics of new hospitals, etc.). In Brazil, this conflict has been openly evidenced among the President of the Republic, the Government, the Ministers of Economy, Health, Science, Technology and Innovation, the Governors and Mayors with opposing and contrary points of view and actions about the measures to be taken during the pandemic.

This communication process and the mismatched interactions among these spheres are referring not only to the type of communication and the logic inherent in each system, but also to the model (and deficits) of federative governance, and to the specific action of the government. These last two factors have been decisive in the fight against the COVID-19 pandemic. Countries with similar federative structures (Germany, Austria) have had effective intermediate institutions and bodies for the resolution of conflicts among counterpointed interests in the interfederative scope. On the other hand, the presidents of Germany and Spain, before any declaration, have been advised by the ministers of health or specialists in pandemics, and these virologists have become the governmental voice. In Sweden, the decisions were made by the Special Emergency Office. In their speeches, they stressed that their decisions were strictly technical and scientific, thus moving away from possible readings or interpretations of political confinement strategies and their direct impacts on the economy. However, these cases must be carefully analyzed, as these countries are very different in political and civic cultures and actions of progressive and conservative governments.

\section{Some provisional reflections}

In the argumentative line of the self-referential systems of this paper, it is possible, at the conceptual level, to distinguish some basic operations of each system influencing itis operations or interferences with respect to other systems, in three basic aspects:

- a basic premise to avoid superficial simplifications of operations carried out by a complex system is to know that these are autonomous systems with the capacity to carry out their own operations regardless of their environment. For this reason, trying to influence them from the outside or being directly interfered by another system may result in other unwanted and even contrary effects. Differentiated functional systems have autonomy and operational closure. In each system, it is required to analyze its contextual orientation, that is, how it takes on the communications and codes coming from its environment, trying to acquire some information and results from this type of orientation;

- the quality of the guidance or intervention will depend on the quality of the understanding of the operating logic of each system. Thus, the science system works in the truth-not truth code, and the health system works in the being attended-not being attended by the health system code. The greater the orientation towards the system and the greater the communicative experience, the better the internal model of the system guiding and directing the orientation strategy; To overcome these limitations of systems theory, the concepts of "configuring contextual orientation" and "power as preconfigured internal orientation" are proposed (VIDAL, 2019, 2021).

- it is required to consider that the communications will be oriented according to the system logic, in accordance with its internal operations. The system will decide what to do with the orientation. The system chooses particular parameters, constraints, and specific opportunities that allow it to react to new parameters, new opportunities, and new constraints. Changes in the environment and on the opportunity map are invitations for the system to react to these changes.

Other central questions also arise for the configuration and regulation of society, "Will a predominance of science over politics take place in the near future?". It is evident that we cannot predict it here, but, under the perspective of self-referential systems, we can describe how the different systems interact and analyze the interconnections and codes rulling the logic of the economic, scientific, and health systems. For the administration, contingency can mean a horizon of possibilities oriented towards participatory and horizontal methods and structures, or centralized and vertical hierarchies in tune with the orientation, reform, and action spheres of the State responsibilities. In the technical and logistical field, multiple different failures have appeared that must be corrected (electronic government, digital administration, transparency). 
In the international macrosocial area, questions emerge ranging from predictions that "nothing will ever be the same again" to apocalyptic scenarios. Different strategies correspond to each of these proposals and intentions, some continuists and others that even aspire to the expected end of capitalism by the radical political sectors.

At the political level, a succession of dismissals and resignations of political and institutional leaders has already begun in practically all countries. The general parliamentary elections scheduled for 2021 and 2022 will measure the confidence that citizens have placed in their respective governments during the pandemic management and will charge how the financing for the payment of emergency health expenses was distributed in public aid policies and emergency measures implemented, and in measures taken for economic reactivation. Proposals, plans, and policies with their effectiveness will also be measured, aimed at mitigating the pandemic economic effects in the coming years. In Brazil, the first test took place in the municipal elections of November 2020 (first round), which highlighted a decrease in the existing polarization in the country, a reorientation towards a conservative center with traditional political forces, although polarization was still being manifested in metropolises as far away as São Paulo and Belém. The "anti-system policy" of the candidates supported by President Jair Bolsonaro, and the former ruling party PT. The State orientation - in this case of the public actions of the municipalities - for a reduced or more extensive kind will not be free from paradoxes, since higher State does not necessarily mean more efficiency, and lower State does not mean more transparency or accountability. Both trends unfold in a contingent social context.

In Brazil, the emergency measures adopted by the government have constituted an essential kind of policy for the most disadvantaged population (as a kind of governmental communication), and the exposed period has been characterized by some central problems of its health governance:

- the domain of contradictory and paradoxical government communications (many strategies of the Ministry of Health) without continuity (change of ministers) and with many fundamentals (economy, health, science);

- the lack of interfederative mechanisms and forums with the capacity to solve conflicts among the Government, the states, and the municipalities comprising the Union;

- the emergence of a deep institutional crisis resulted from interferences among powers (Judicial, Legislative, Executive), crystallized between the President of the Republic and the Superior Court of Justice.

Brazil has not been the only western country to which these three conflicts have converged, although their nature and depth must be analyzed and rethought.

In short, the collapse of leaders, governments, coalitions, and ruling parties is looming. How will the society-State relationship be delineated? How will management and administration be configured with the emergence of new State models? Will the context of alarm and the disempowerment of the Legislative with respect to the Executive be maintained? These are questions going beyond this paper and to understand the entire relationship and the desired social organization model will be important. Empirical verifications on the hypotheses presented, on how the State models will be imposed and implemented, and how it will affect the administrations will be required. However, the fundamental question at the collective and subjective level will be, "What kind of society do we want?". 


\section{REFERENCES}

ABREU, J. C. A. Participação democrática em ambientes digitais: o desenho institucional do orçamento participativo digital. Cadernos EBAPE.BR, Rio de Janeiro, v. 14, n. 3, p. 794-820, 2016. Available at: <http://bibliotecadigital.fgv.br/ojs/index.php/ cadernosebape/article/view/31558/62052>. Accessed on: Nov. 30, 2020.

ALFORD, J. Public value pragmatism as the next phase of public management. American Review of Public Administration, v. 38, n. 2, p. 130-148, 2008. Available at: <https://www.researchgate. net/publication/236325742_Public_Value_Pragmatism_as_the Next_Phase_of_Public_Management>. Accessed on: Nov. 30, 2020.

ALFORD, J.; HUGHES, O. Public Value Pragmatism as the Next Phase of Public Management. The American Review of Public Administration, v. 38, n. 2, p. 130-148, 2008. Available at: <https:// www.researchgate.net/publication/236325742_Public_Value_ Pragmatism_as_the_Next_Phase_of_Public_Management $>$. Accessed on: Nov. 30, 2020.

BARBA SOLANO, C. América Latina: regímenes de bienestar en transición durante los años noventa. Cad. CRH, v. 20, n. 50, p. 197-211, 2007. Available at: <https://www.scielo.br/scielo. php?script=sci_arttext\&pid=S0103-49792007000200002 $>$. Accessed on: Nov. 30, 2020.

BECK, U. La sociedad del riesgo: Hacia una nueva modernidad. Barcelona: Paídos Ibérica, 1998.

BOGUMIL, J. (Org.). Zehn Jahre Neues Steuerungsmodell: Eine Bilanz kommunaler Verwaltungsmodernisierung. Berlin: Edition Sigma, 2007.

BOVAIRD, T.; LOEFflER, E. User and community co-production of public services and public policies through collective decisionmaking: the role of emerging technologies. In: BRANDSEN, Y.; HOLZER, M. (Ed.). The Future of Governance. Newark: NCPP, 2009. p. 231-251.

CAVALCANTE, P. L.; CAMÕES, M. R. S. Gestão pública no Brasil: as inovações configuram um novo modelo? In: CONGRESSO CONSAD GESTÃO PÚBLICA, 8., 2015, Brasília, DF. Anais... Brasília, DF: COMSAD, 2015. Available at: <http://www.gestaopublica.unb.br/images/ alunoregular/cavalcante-et-al.-2015.pdf>. Accessed on: Nov. 30, 2020.

CHUNG-PIN, L.; CHANG, K.; BERRY, F. S. Testing the Development and Diffusion of E-Government and E-Democracy: A Global Perspective. Public Administration Review, v. 71, n. 3, p. 444-454, 2011.

COSTA, G.; DUTRA, T. Big Data: novas possibilidades para avaliação e resposta a riscos em demonstrações financeiras do Governo Federal.
Revista do Tribunal de Contas da União, v. 46, n. 131, p. 54-61, 2014. Available at: <https://revista.tcu.gov.br/ojs/index.php/RTCU/article/ view/62>. Accessed on: Nov. 30, 2020.

EVERS, C.; WU, E. On generalizing from single case studies: Epistemological reflections. Journal of Philosophie of Education, n. 40, p. 511-526, 2006.

GLOBAL PREPAREDNESS MONITORING BOARD - GPMB. Un mundo en peligro: Informe anual sobre la preparación mundial sobre las emergencias sanitarias. Geneva: Junta de Vigilancia Mundial de la Preparación, 2019.

LUHMANN, N. Ökologische Kommunikation: Kann die moderne Gesellschaft sicj auf ökologische Gefährdungen einstellen?. Opladen: Wetsdeutscher Verlag, 1988.

LUHMANN, N. Sociología política. Madrid: Trotta, [2010]2014.

LUHMANN, N. Teoría política en el estado de Bienestar. Madrid: Alianza, [1981]1993.

MOLDASCHL, M.; MANGER, D. Institutionelle Reflexivität in der öffentlichen Verwaltung. In: MOLDASCHL, M.; MANGER, D. (Org.). Im Spiegel der Organisation: Innovationsfähigkeit durch institutionelle Reflexivität. France: Hampp, 2016. p. 63-86.

OLIVEIRA, M. A verdade por trás do Big Data: o grande problema do século 21. Inteligencia corporativa, Florida, Apr. 25, 2018. Available at: <https://inteligencia.rockcontent.com/verdade-do-big-data/>. Accessed on: Nov. 30, 2020.

SOUSA, K. J.; OLIVIERI, C. Cooperação intergovernamental na política de saúde: a experiência dos consórcios públicos verticais no Ceará, Brasil. Cadernos de Saúde Pública, v. 36, n. 3, e00037519, 2020. Available at: <https://scielosp.org/article/csp/2020.v36n3/ e00037519/>. Accessed on: Nov. 30, 2020.

VIDAL J. Governança democrática: Para uma nova coordenação da sociedade. Rio de Janeiro, Tirant Lo Blanch Brasil, 2019.

VIDAL, J. (Coord.). Da governança hierárquica a interativa. Belém: Paka-Tatu, 2018.

VIDAL, J. (Coord.). Observando la Gobernanza. Visiones desde la Amazonia (Working papers, n. 83-90). Natal: GIGAPP estudios, 2018. p. 90-241. Available at: <http://www.gigapp.org/ewp/index.php/ GIGAPP-EWP/issue/view/54/7>. Accessed on: Nov. 30, 2020.

VIDAL, J. Sociedades contingentes: Transformações da sociedade política. 2021. En prelo.

Josep Pont Vidal

ORCID:https://orcid.org/0000-0002-6214-6895

Graduated in Political Sociology by Universität Bielefeld, Germany; Dr. in Political Sociology by the University of Barcelona; Associate Professor at the Federal University of Pará at the Center for High Amazon Studies (NAEA, Brazilian); Professor of Public Administration and Theory of Organizations, Belém - PA, Brazil. E-mail: josevidal@ufpa.br 